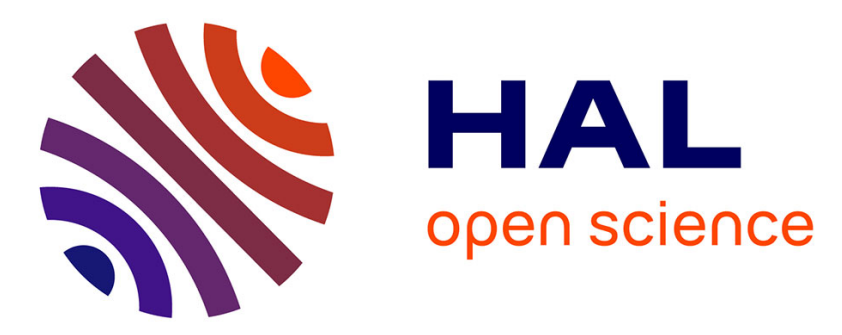

\title{
Value Co-creation in the Context of Digitally-enabled Product-Service Systems
}

\author{
Oliver Stoll, Wenting Zou, Eugen Rodel, Shaun West
}

\section{To cite this version:}

Oliver Stoll, Wenting Zou, Eugen Rodel, Shaun West. Value Co-creation in the Context of Digitallyenabled Product-Service Systems. 22nd Working Conference on Virtual Enterprises (PRO-VE 2021), Nov 2021, Saint-Etienne, France. pp.337-344, 10.1007/978-3-030-85969-5_30 . emse-03339374

\section{HAL Id: emse-03339374 \\ https://hal-emse.ccsd.cnrs.fr/emse-03339374}

Submitted on 24 Nov 2021

HAL is a multi-disciplinary open access archive for the deposit and dissemination of scientific research documents, whether they are published or not. The documents may come from teaching and research institutions in France or abroad, or from public or private research centers.
L'archive ouverte pluridisciplinaire HAL, est destinée au dépôt et à la diffusion de documents scientifiques de niveau recherche, publiés ou non, émanant des établissements d'enseignement et de recherche français ou étrangers, des laboratoires publics ou privés. 
Stoll O., Zou W., Rodel E., West S. (2021) Value Co-creation in the Context of DigitallyEnabled Product-Service Systems. In: Camarinha-Matos L.M., Boucher X., Afsarmanesh H. (eds) Smart and Sustainable Collaborative Networks 4.0. PRO-VE 2021. IFIP Advances in Information and Communication Technology, vol 629. Springer, Cham. https://doi.org/10.1007/978-3-030-85969-5_30

\title{
Value Co-creation in the Context of Digitally-enabled Product-Service Systems
}

\author{
Oliver Stoll ${ }^{1}$, Wenting Zou ${ }^{2}$, Eugen Rodel ${ }^{3}$, Shaun West ${ }^{1}$ \\ ${ }^{1}$ Institute of innovation and Technology Management, Lucerne University of Applied \\ Sciences and Arts, 6048 Horw, Switzerland \\ ${ }^{2}$ Industrial Engineering and Management, Aalto University, \\ 00076 Aalto, Finland \\ ${ }^{3}$ thingminds, 8853 Lachen SZ, Switzerland
}

\begin{abstract}
This paper describes the development of a conceptual framework to support the identification of value co-creation within the context of digitallyenabled Product-Service Systems (PSS). The framework was developed based on five themes. It considers how and where value co-creation occurs and also the translation of data into information that can become knowledge for individuals and organizations within the digitally-enabled PSS context. The model brings together the different actors and beneficiaries with a governance process that focuses on supporting value co-creation by integrating the information with data. The framework supports new innovation and improvements to existing PSS.
\end{abstract}

Keywords: value co-creation; product-service system; digitalization; servitization; lifecycle; service-dominate logic.

\section{Introduction}

As servitizing activities proliferate within industries, the research focusing on ProductService System (PSS) advances in line with the research on service-dominant (S-D) logic $[1,2]$. Manufacturing firms with servitization strategies are moving to PSS-based business models to gain more stable income [3]. Prior studies demonstrate that successful PSS strategies can fulfill diverse customer needs and enhance resource efficiency by extending product lifecycles[4].

Despite these potential benefits, adopting PSS proves complex for firms for designing and implementing successful service strategies [5]. This is because PSS provides a complex environment consisting of multiple actors, stakeholders, and beneficiaries in the context of servitization [6] and the machines within the system. A paradox is developing that hinders exploitation of digitally-enabled solutions in PSS [7]; it is due to the transformational aspects of digitally-enabled PSS and servitization[8]. A lifecycle perspective is useful when considering data and information flows and how they can assist value creation [9]. Value co-creation has been identified as a complex process in this context and requires further investigation. 
This study aims to explore this in digitally-enabled Product-Service Systems (PSS) along the lifecycle. It provides initial input into a framework that supports value cocreation in digitally-enabled PSS, which will then be developed further. .

\section{Research Framework and Methodology}

PSS and servitization are mature fields that are closely tied to lifecycle management and value co-creation. The application of S-D logic is a core tenet of servitization, notably within the definition of advanced services $[1,2,3]$. The concept of value (identification, creation and capture) in digitally-enabled PSS in industry however, remains poorly researched over the lifecycle. The literature remains generally fragmented, with limited integration from different research fields. For this reason, an integrative literature review has been chosen as the most appropriate approach, bounded by the concept of PSS in an industrial context, the product lifecycle, and value cocreation, allowing the integration of knowledge from other disciplines [10]. The review outcome will be a theoretical framework that can be applied, tested, and improved in the future.. The literature has primarily been selected from the Web of Science. Selection of relevant and insightful literature was initially based on keywords, title and abstract: "value co-creation" OR "value creation" OR "value propositions" AND "manufact*".

\section{Integrative Literature Review}

Based on the thematic content analysis investigating the aspects of value co-creation, papers were analyzed into five categories: value creation processes, lifecycle governance of value co-creation, PSS based value propositions, value creation and advanced services, and value creation in the digitally-enabled PSS. The literature is summarized in Table 1 segmented based on these five categories. The number of papers identified is given, along with the key references used to build up the sub-sections in this literature review. They support building an initial framework that supports value co-creation over the lifecycle of PSS. 157 papers were found initially, before the final selection in Table 1, where the papers used in each critical review are listed,

Table 1. Overview of the literature

\begin{tabular}{lcc}
\hline Theme & Papers & Cross-related to themes \\
\hline Value creation processes & 11 & 7 \\
Lifecycle governance of value co-creation & 8 & 0 \\
PSS based value propositions & 6 & 1 \\
Value creation and advanced services & 15 & 13 \\
Value creation in digitally-enabled PPS & 15 & 9 \\
\hline
\end{tabular}




\subsection{Value Creation Processes}

To create value, two actors must be involved in a service ecosystem [11]. The value cocreation process is based on the integration of their explicit and tacit knowledge to develop a solution [12], the ecosystem is important because many actors and machines can be involved in the value creation process [13]. Shedroff [14] applies aspects of interaction design to understand value co-creation in terms of control/feedback, productivity and adaptability, this is in line with SD logic [15]. Value co-creation is not a single event, Grönroos [16] expanded on this along the product lifecycle with a focus on the beginning of life and the middle of life [17]. Bertoni et al., [18] visualized the links between value in use and value in exchange. Journey mapping can also be used to investigate the value co-creation processes $[19,20]$. Describing value (i.e., financial, tangible, intangible, etc.) to parties who are involved demonstrates the outcomes to the stakeholders and the beneficiaries [21].

\subsection{Lifecycle Governance of Value Co-creation}

Value co-creation in an advanced service agreement occurs over the product's whole lifecycle providing opportunities to create value, which is described as 'sharing pains and gains' in some contexts [1,22]. Advanced service providers are dependent on the ecosystem's resources to achieve the desired performance [23,24]. Changes to laws and partner behaviors, technologies, or markets may shift the equilibrium of value cocreation and require a realignment to achieve a new win-win position [25]. Institutional arrangements are necessary to support the re-alignment and hence governance of the value co-creation and resource integration [26]. Generally, the more successful forms of contact were longer-term oriented and reflected collaborative working [27]. However, role ambiguities were identified as key challenges in the servitization process.

\subsection{PSS based Value Propositions}

Servitization strategies may be delivered by a firm through PSS, as it enables them to create more value for customers and has aspects of SD logic embedded within [3]. The approach (together with digital servitization) provides customer integration and models that focus on value co-creation and capture [7]. The classification of the value propositions within a PSS context has been developed to support the understanding of the services (revenue model and nature of the value proposition) [28]. For digitallyenabled PSS a model has been proposed that provides additional insights into the value propositions [7]. This work agrees with others that describe new digitally-enabled value co-creation in PSS contexts $[29,30]$, where value capture can be problematic as firms fail to change business models [31]. 


\subsection{Value Creation and Advanced Services}

Advanced services focus on the outcomes delivered through the product's performance $[31,33]$. These outcomes are based on explicit and tacit knowledge being exchanged among different actors. Digitalization can support the exchange of information to increase perceived 'customer value' [31]. The delivery of advanced services requires many actors to deliver the expected performance, and value is often co-delivered for the beneficiary [34]. The development of digitally-enabled PSS takes place with the customer through a process of value co-creation [16]. As a company moves towards advanced services, the product becomes a distribution mechanism for the services as the firm shifts into SD logic from goods-based logic $[2,15]$. Advanced services require a firm to reframe its position within the value creation process over the whole lifecycle, reinforcing the SD logic $[12,2]$. The integrator's role to moderate interactions for value co-creation in industrial settings has been investigated $[35,36]$. Within SD logic, value co-creation is supported by integrators (or moderators) applying resources along the lifecycle to help customers in their own value-creation processes $[2,12,15]$. Information and interaction design can be supported with digital tools, supporting the integrator to transform data into knowledge [14]. The interrelationship between data, information, knowledge, and wisdom, are explored in the literature [37,38,39].

\subsection{Value Co-creation in the Digitally-enabled PPS}

Data alone cannot create value [40]. The difference between data and information is not structural but functional [38]; visualization makes it meaningful [18]. Data can be considered information only if organized, presented as relevant, usable, significant, or meaningful answers [41]; only then can knowledge be built up through multiple interactions [42]. Knowledge originates from information integration and exchange, which in turn generates experience [39]. According to the literature [2,15], value in PSS delivery is continuously created through interactions between multiple actors, who act as the resource integrators, forming ecosystems of service offerings and exchanges [43]. It is co-generated through the reciprocal application of resources by the integrators to benefit a receiving entity [2]. The system integrator orchestrates the ecosystem in such a configuration allowing actors to contribute actively [44]. Value co-creation can be achieved by establishing different types of participant engagement; value capture needs the active involvement of at least two actors in the service ecosystem [45].

\section{Framework for Value Co-creation in Digitally-enabled PSS}

In this study, the framework developed (Figure 1), based on the literature, supports value co-creation in digitally-enabled PSS in an industrial context. In many cases, the operational life of the equipment is tens of years., This is a limitation on the framework, although, it provides a clear set of boundaries be later validate. The framework builds upon the five thematic blocks, providing an initial framework to support value cocreation. The framework is based on dyadic relationships as this is simpler than triadic 
(or more). The framework supports and promotes the exchange of explicit and implicit knowledge to be integrated into a solution delivering the value co-creation process for the beneficiaries [12]. The framework applies feedback between the parties, supporting productivity, and adaptability from integration design, to aid build knowledge (within and between different life cycle phases).

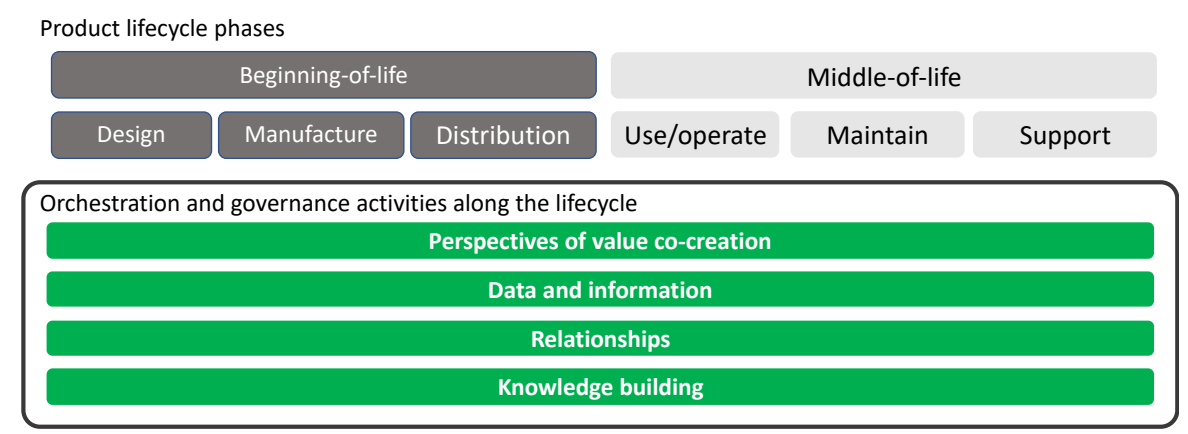

Figure 1. Framework to supporting value co-creation along the product lifecycle

The integration of the actors at each phase of the lifecycle and between each phase, needs orchestration to ensure two-way flows [9]. Each touchpoint or transaction between actors provides an opportunity for value co-creation. Starting from the beginning of life, value co-creation is possible, although in PSS there is a tendency for a good-dominant logic approach to apply. During the middle of life, there are many situations where value co-creation and co-delivery can occur, and the impulse may be from people, operational, or technology changes. Here it is necessary to adapt to maximize the value co-creation and value capture opportunities and share the lessons with the installed base and to the team focused on the beginning of life phase. To achieve value co-creation across the lifecycle, four aspects identified from the literature form the basis of the framework: i. perspectives of value co-creation; ii. data and information; iii. relationships between actors; and iv. knowledge building. The connections between the beginning of life and middle of life must be actively supported and encouraged (orchestrated via the support of a resource integrator).

Building long-term relationships, based on institutional structures (e.g., contracts), between the actors in the ecosystem is essential to support the orchestration and governance of value co-creation (via a moderator/resource interrogator) [19,20]. Value is generally co-created through in-depth interactions and intensive capability integration between the actors. These interactions are based on exchanging data, information, and knowledge between many actors who are in effect participating in value co-creation over the lifecycle for a range of beneficiaries. Moderators/resource interrogators support the relationship between different actors in the ecosystem and are in effect "valuable bridges, as they give one actor access to the resources of another" [46, p68]. 


\section{Conclusions and Recommendations}

The integrative literature review unifies different research themes from different academic perspectives and creates a framework to support value co-creation over the PSS lifecycle. This is particularly important where there is a digital aspect to the system. The framework created needs to be tested and refined, while further research is needed in the multidisciplinary area.

The framework supports value co-creation along the PSS lifecycle. It confirms that firms need to determine new approaches for collaboration to improve value co-creation and co-delivery processes and allow them to adapt over the full life cycle of the PSS. Digitalization increases the availability of data and derived information, and though orchestrated collaboration this can be used to support value co-creation through a closer collaborative approach. Therefore, companies moving towards digital transformation would enhance value co-creation during their products' lifecycle.

\section{References}

1 Reim, W., Parida, V., \& Örtqvist, D. (2015). Product-Service Systems (PSS) business models and tactics - A systematic literature review. Journal of Cleaner Production. https://doi.org/10.1016/j.jclepro.2014.07.003

2 Vargo, S. L., \& Lusch, R. F. (2008). From goods to service(s): Divergences and convergences of logics. Industrial Marketing Management, 37(3), 254-259. doi:10.1016/j.indmarman.2007.07.004

3 Baines, T. S., Lightfoot, H. W., Benedettini, O., \& Kay, J. M. (2009). The servitization of manufacturing: A review of literature and reflection on future challenges. Journal of Manufacturing Technology Management, 20(5), 547-567. doi:10.1108/17410380910960984

4 Tukker, A. (2004). Eight types of product-service system: eight ways to sustainability? Experiences from SusProNet. Business strategy and the environment, 13(4), 246-260.

5 Zou, W., Brax, S. A., \& Rajala, R. (2018). Complexity in product-service systems: review and framework. Procedia CIRP, 73(1), 3-8.

6 Kuijken, B., Gemser, G., \& Wijnberg, N. M. (2017). Effective product-service systems: A value-based framework. Industrial Marketing Management, 60, 33-41. doi:10.1016/j.indmarman.2016.04.013

7 Kohtamäki, M., Parida, V., Oghazi, P., Gebauer, H. \& Baines, T. (2019). Digital servitization business models in ecosystems: A theory of the firm. Journal of Business Research, 104(June), 380-392. https://doi.org/10.1016/j.jbusres.2019.06.027

8 Tronvoll, B., Sklyar, A., Sörhammar, D. \& Kowalkowski, C. (2020). Transformational shifts through digital servitization. Industrial Marketing Management. https://doi.org/10.1016/j.indmarman.2020.02.005

9 Wuest, T., Wellsandt, S., \& Thoben, K. D. (2016). Information quality in PLM: A production process perspective. In IFIP Advances in Information and Communication Technology. https://doi.org/10.1007/978-3-319-33111-9_75

10 Snyder, H. (2019). Literature review as a research methodology: An overview and guidelines. Journal of Business Research, 104. https://doi.org/10.1016/j.jbusres.2019.07.039

11 Raja, J. Z., Frandsen, T., Kowalkowski, C., \& Jarmatz, M. (2020). Learning to discover value: Value-based pricing and selling capabilities for services and solutions. Journal of Business Research, 114, 142-159. doi:10.1016/j.jbusres.2020.03.026 
12 Valtakoski, A. (2017). Explaining servitization failure and deservitization: A knowledgebased perspective. Industrial Marketing Management. https://doi.org/10.1016/j.indmarman.2016.04.009

13 Payne, A. F., Storbacka, K., \& Frow, P. (2008). Managing the co-creation of value. Journal of the Academy of Marketing Science, 36(1), 83-96. doi:10.1007/s11747-007-0070-0

14 Shedroff, N. (1999). Information interaction design: A unified field theory of design. Information design, 267-292.

15 Vargo, S. L., \& Lusch, R. F. (2004). Evolving to a new dominant logic for marketing. Journal of Marketing, 68(1), 1-17. doi:10.1509/jmkg.68.1.1.24036

16 Grönroos, C. (2011). Value co-creation in service logic: A critical analysis. Marketing Theory. https://doi.org/10.1177/1470593111408177

17 Terzi, S., Bouras, A., Dutta, D., Garetti, M., \& Kiritsis, D. (2010). Product lifecycle management - From its history to its new role. International Journal of Product Lifecycle Management. https://doi.org/10.1504/IJPLM.2010.036489

18 Bertoni, A., Bertoni, M., \& Isaksson, O. (2013). Value visualization in Product Service Systems preliminary design. Journal of Cleaner Production, 53, 103-117. doi:10.1016/j.jclepro.2013.04.012

19 Lemon, K. N., \& Verhoef, P. C. (2016). Understanding customer experience throughout the customer journey. Journal of Marketing, 80(6), 69-96.

20 Paiola, M., \& Gebauer, H. (2020). Internet of things technologies, digital servitization and business model innovation in BtoB manufacturing firms. Industrial Marketing Management, 89, 245-264. doi:https://doi.org/10.1016/j.indmarman.2020.03.009

21 Kambanou, M. L., \& Lindahl, M. (2016). A Literature Review of Life Cycle Costing in the Product-Service System Context. In S. Cavalieri, E. Ceretti, T. Tolio, \& G. Pezzotta (Eds.), Product-Service Systems across Life Cycle (Vol. 47, pp. 186-191). Amsterdam: Elsevier Science Bv.

22 Hou, J. C., \& Neely, A. (2018). Investigating risks of outcome-based service contracts from a provider's perspective. International Journal of Production Research, 56(6), 2103-2115. doi:10.1080/00207543.2017.1319089

23 Kim, S.-H., Cohen, M. a., and Netessine, S. (2007). Performance Contracting in After-Sales Service Supply Chains. Management Science, 53 (12), 1843-1858.

24 Story, V.M., Raddats, C., Burton, J., Zolkiewski, J., and Baines, T., 2017. Capabilities for advanced services: A multi-actor perspective. Industrial Marketing Management, 60, 54-68.

25 Chesbrough, H. and Schwartz, K., 2007. Innovating Business Models with Co-Development Partnerships. Research-Technology Management, 50 (1), 55-59

26 Frost, R.B.; Cheng, M.; Lyons, K. (2019) A Multilayer Framework for Service System Analysis. In Handbook of Service Science; Maglio P., Kieliszewski C., Spohrer J., Lyons K., Patrício L., Sawatani Y., Eds.; Service Science: Research and Innovations in the Ser-vice Economy. Springer: Cham, Switzerland, 2019; Volume II, doi:10.1007/978-3-319-985121 13.

27 Kowalkowski, C., \& Ulaga, W. (2017). Service Strategy in Action: A Practical Guide for Growing Your B2B Service and Solution Business: Service Strategy Press.

28 Rönnberg Sjödin, D., Parida, V., and Wincent, J., 2016. Value co-creation process of integrated product-services: Effect of role ambiguities and relational coping strategies. Industrial Marketing Management.

29 Kristensen, H. S., \& Remmen, A. (2019). A framework for sustainable value propositions in product-service systems. Journal of Cleaner Production, 223, 25-35. doi:10.1016/j.jclepro.2019.03.074

30 Paschou, T., Rapaccini, M., Adrodegari, F. \& Saccani, N. (2020). Digital servitization in manufacturing: A systematic literature review and research agenda. Industrial Marketing Management, (November 2019), 0-1. https://doi.org/10.1016/j.indmarman.2020.02.012 
31 Gebauer, H., Fleisch, E., Lamprecht, C., \& Wortmann, F. (2020). Growth paths for overcoming the digitalization paradox. Business Horizons. doi:10.1016/j.bushor.2020.01.005

32 Calabrese, A., Levialdi Ghiron, N., \& Tiburzi, L. (2020). 'Evolutions' and 'revolutions' in manufacturers' implementation of industry 4.0: a literature review, a multiple case study, and a conceptual framework. Production Planning and Control. https://doi.org/10.1080/09537287.2020.1719715

33 Naik, P., Schroeder, A., Kapoor, K., Ziaee Bigdeli, A., \& Baines, T. (2019). Behind the Scenes of Digital Servitization: Actualizing IOT-Enabled Affordances. Academy of Management Proceedings. https://doi.org/10.5465/ambpp.2019.12804abstract

34 Grubic, T., \& Jennions, I. (2018). Do outcome-based contracts exist? The investigation of power-by-the-hour and similar result-oriented cases. International Journal of Production Economics, 206, 209-219. doi:10.1016/j.ijpe.2018.10.004

35 Hertog, P. Den. (2000). Knowledge-intensive business services as co-producers of innovation. International Journal of Innovation Management. https://doi.org/10.1142/s136391960000024x

36 Kohtamäki, M., \& Partanen, J. (2016). Co-creating value from knowledge-intensive business services in manufacturing firms: The moderating role of relationship learning in suppliercustomer interactions. Journal of Business Research. https://doi.org/10.1016/j.jbusres.2016.02.019

37 Liew, A. (2007). Understanding data, information, knowledge and their inter-relationships. Journal of knowledge management practice, 8(2), 1-16.

38 Aven, T. (2013). A conceptual framework for linking risk and the elements of the datainformation-knowledge-wisdom (DIKW) hierarchy, Reliability Engineering \& System Safety, 111, March 30-36.

39 Bagheri, S., Kusters, R., \& Trienekens, J. (2015). The Customer Knowledge Management Lifecycle in PSS Value Networks: Towards Process Characterization. In M. Massaro \& A. Garlatti (Eds.), Proceedings of the 16th European Conference on Knowledge Management (pp. 66-77).

40 Lee, J., Kao, H. A. \& Yang, S. (2014). Service innovation and smart analytics for Industry 4.0 and big data environment. In Procedia CIRP. https://doi.org/10.1016/j.procir.2014.02.001

41 Rowley, J. (2007). The wisdom hierarchy: Representations of the DIKW hierarchy. Journal of Information Science. https://doi.org/10.1177/0165551506070706

42 Choo, C. W. (2007). The knowing organization: How organizations use information to construct meaning, create knowledge and make decisions. International Journal of Information Management. Volume 16, Issue 5, October 1996, Pages 329-340. https://doi.org/10.1016/0268-4012(96)00020-5

43 Sklyar, A., Kowalkowski, C., Sörhammar, D., \& Tronvoll, B. (2019). Resource integration through digitalisation: a service ecosystem perspective. Journal of Marketing Management. https://doi.org/10.1080/0267257X.2019.1600572

44 Kindström, D. and Kowalkowski, C. (2014). Service innovation in product-centric firms: A multidimensional business model perspective, Journal of Business \& Industrial Marketing, 29(2), 151-163.

45 Anderson, J.C., Narus, J.A. and Van Rossum, W. (2006). Customer value propositions in business markets, Harvard Business Review, 84(3), 2-10.

46 Harland, C. M. (1996). Supply chain management: relationships, chains and networks. British Journal of management, Vol. 7 No. S1, pp. S63-S80. 